\title{
Old Age in Cinema: A Reevaluation of Sorrentino's Youth
}

\author{
Ephraim David \\ University of Haifa
}

\begin{abstract}
Paolo Sorrentino's film Youth has been severely criticized by professional reviewers for a series of alleged faults. This review attempts to use a multi-disciplinary approach in order to challenge the validity of most criticisms and to elucidate the importance of this film as a work of art focused on the problems of aging. The discussion stresses the binary structure of the plot and the film's intensive use of dichotomies, such as memory/amnesia, speech/silence, ambition/apathy, divine beauty/grotesque ugliness, and especially youth/old age. The paper also brings into high relief the prevalent melancholic atmosphere of this film, which conveys through a long series of related metaphors, associations and sounds, the general impression of a cinematic elegy (or threnody). Other topics discussed include the deep influence of classical tradition on Sorrentino's methodology, patterns of nonverbal communication and the artistic manipulation of nudity. Far from being an "emotionally paralyzed" and "simplistic" film (as many critics have asserted), in my view Youth is a sophisticated, subtle and profoundly humane depiction of old age, particularly as far as artists are concerned. It is typical of Sorrentino's preoccupation with aging, as reflected by some of his other films as well, e.g. The Great Beauty and the more recent Loro.
\end{abstract}

Keywords: Melancholy; classical tradition; music; emotions.

\section{Purpose and Methodology}

Old age has been treated in literature, philosophy and plastic art since antiquity: in epic and lyric poetry, tragedy, comedy, philosophical treatises as well as paintings and sculptures. It has also been a subject of many films. In this paper I propose to analyze in depth a relatively recent representation of old age in cinema: Paolo Sorrentino's film, Youth (2015).

At the time this film was received with mixed feelings by professional cinema critics. Their reviews displayed a mixture of criticism and praise, but in most cases praise was quantitatively meagre and reserved, while criticism was severe and abundant. Frequently, praise appeared to be confined to the fascinating tableaux (Luca Bigazzi's shots), the actors' virtuosity and David 
Lang's music, while criticism covered a wide range of alleged flaws: the lack of a proper plot and of significant emotions; ${ }^{1}$ a fragmented structure and slow-paced rhythm; ${ }^{2}$ dullness of the script and predilection for clichés $;^{3}$ lack of substance and depth; ${ }^{4}$ abuse of nudity coupled by phallocentric and sexist traits; ${ }^{5}$ being marooned mostly on a single location and focused on the wealthy. ${ }^{6}$ Many reviewers also evaluated Youth by briefly comparing it (unfavorably) with $L a$ Grande Bellezza (The Great Beauty, 2013) -- a previous work of the same Italian film director and screenwriter, focused to a great extent also on old age. ${ }^{7}$ At times criticism was accompanied by some sarcastic, arbitrary and quasi-abusive comments. ${ }^{8}$

This sounds like a chorus of disapproval, perhaps echoing the booing at the Cannes premiere. There were different voices as well (though fewer by far) which, on the whole, were significantly more favorable. ${ }^{9}$ But all these reviews, regardless of their opinions, had something in common: their "verdict" was based on a highly brief and impressionistic report, which certainly could not do justice to the film. I have written this paper out of my belief that Youth deserves more careful attention and that a closer examination may demonstrate that even from a relatively short time perspective it may be considered as a significant work of art misjudged by too many critics. It is above all a major contribution to the depiction of old age on the cinema screen. As far as methodology is concerned, I shall use a mutli-disciplinary approach: various tools from the fields of classics and literature, sociology, psychology, gerontology, art history, communication and cinema studies. Only such a multi-disciplinary approach can, in my view, do justice to this film as a work of art.

\section{Findings and Implications}

Indeed, old age is the main preoccupation of Youth, and the subject is treated throughout with remarkable sophistication and finesse. The title is ambiguous since, in addition to its inherent inversion irony, it reflects a double contemplation of the elderly: on their own youth as well as on the young people surrounding them. The idea of inversion encapsulated in the title is developed through a series of other contrasts such as memory/ amnesia, speech/ silence, ambition/apathy, divine beauty/ grotesque ugliness, dreams or hallucinations/ reality, classical or post-romantic music/ pop and rock music, seriousness/ levity. Dichotomy also operates through contrasting or disjunctive images and parallel acoustic effects of dissonance striking the spectator with their intensity and rhythm (by the way, similarly to The Great Beauty).

Although many readers are probably familiar with the plot, a brief survey is not out of place; moreover, on the methodological level it provides the background for challenging the validity of the above criticisms. The plot takes place most of the time in an elitist Swiss spa, an Alpine resort containing a rich gallery of eccentric characters, some of them caricatures, such as a grotesquely obese middle-aged retired football player (a caricature of Diego Maradona), bearing a huge Karl Marx tattoo on his back. The film's two main protagonists, two artists in their late seventies, spend their vacation in that spa: the British celebrated composer Fred Ballinger, ${ }^{10}$ former conductor of the Venice Symphony Orchestra, and the American film director Mick Boyle (played with magisterial sensitivity and dexterity by Michael Caine and Harvey Keitel respectively). Fred, portrayed as a man blasé par excellence, is totally reconciled with his retirement and present disengagement. Mick, still professionally engaged, is there on an active 
vacation, accompanied by a team of five young screenwriters (a sort of mini tragi-comic and allegoric chorus), meant to assist him in preparing his artistic "testament" through a new film (entitled ironically Life's Last Day). Though strikingly different in temperament and manners, the two share a life-long friendship, which has been consolidated by years of loneliness: Fred's wife, struck by senile dementia, had been hospitalized long ago in Venice, while Mick's wife had abandoned him. Fred is accompanied by his daughter and assistant, Lena (Rachel Weisz, admirably sensitive in the role), who has been abandoned by Mick's son for a pop singer. Even the marital breakdown of their children does not affect the friendship between the two protagonists, who share daily geriatric preoccupations with their prostate and mnemonic problems, observations about the characters surrounding them and past memories. A refreshing encounter in the film is that between old Fred and a child playing a leitmotif from one of his youthful compositions, Simple Songs.

The main plot is quite simple, and its axis, which marks the beginning and the end of the film, as a circle, is the British Queen's invitation to Fred to conduct in honor of her husband's birthday anniversary his favorite piece, Simple Songs, and then be knighted on that occasion. Fred's refusal "on personal grounds" is disclosed later as being based on his deep feelings for his wife: he had composed the vocal part of that work for her and is not ready to see her interpretation replaced by any other. The spectator is moved by the emotions lurking behind Fred's cold and cynical façade. The depth of those emotions is revealed by one the film's most spectacular sequences: Fred's bizarre hallucination of Venice by night under water, closing with an excruciating cry of pain and horror - "Melany!" - his wife's name.

At this juncture, I shall elaborate on the additional plot of a concentric circle -- that concerned with the other protagonist, Mick, and his cinematic project, because the tragic structure of this plot and its connection with old age were missed by reviewers. Its turning point is provided by the surprising visit of Brenda Morel (Jane Fonda), a veteran Hollywood diva, Mick's favorite actress for more than fifty years, whom he had hoped to be the savior of his project both on the artistic and the financial level. At the news of her arrival, as if she were a dea ex machina ("a goddess from a machine"; in this case from a transatlantic fight), he runs enthusiastically to meet her, leaving the pool where at the time he and Fred were admiring (frustratingly) a fully naked young "goddess", Miss Universe - a scene which, by the way, unmistakably invokes the motif of "Susanna and the Elders" in art history. ${ }^{11}$ In a typically tragic reversal (peripeteia, in Aristotelian terms), ${ }^{12}$ Mick learns about Brenda's decision to abandon his project (a sort of reduplication of his wife's betrayal) for a paying role in a television serial. Moreover, Brenda reveals, rudely and mercilessly, her opinion about the abrupt artistic decline old age had brought on him and claims that by pulling out she is saving his dignity and his life (the dramatic irony becomes soon obvious). In classical terms, their dialogue exhibits a central agon (the confrontation between two characters of the drama), including diametrically opposite perspectives and beliefs about artistic commitment and abrogation, cinema and television, loyalty and ingratitude, spiritual and material values, youth and old age. ${ }^{13}$ By the way, this confrontation is reminiscent of Arthur Miller's style and world of ideas. Shortly after, there comes a real coup de théâtre: broken by the revelation of his geriatric transformation (his artistic impotence) coming from his "muse," Mick jumps to his death leaving his friend paralyzed and perplexed - an anomic type of suicide, in Durkheim terms, i.e. an act stemming from disillusionment and despair. ${ }^{14}$ Subsequently, in a scene hard to digest, taking place in a plane, to stress the claustrophobic effect, Brenda is displayed in a violent attack of hysteria, which brings 
even more into focus some physiologically ruinous effects of old age shown earlier. Fonda deserves praise not only for her magisterial interpretation of this cameo role, but also for having the courage to accept it, particularly in view of the gerophobia prevalent in American mentality.

Paradoxically, Brenda fulfills in a way the classical function of a dea ex machina by moving the plot forward and preparing for the dénouement: she pushes Mick towards life's last day (ironically, his film's title); through his suicide, he leaves a sort of "testament": without artistic engagement, life has no meaning, even at an advanced age. It is this message which appears to bring a transformed Fred to fulfill in his own artistic field, music, Mick's dream of leaving a legacy through an ultimate performance.

By the end of the film Fred returns to conduct the composition of his youth at the royal concert, the vocal part being performed by a Korean lyric soprano (Sumi Jo), but in his imagination he can see his wife, not as she had looked in her glorious days, but as he had seen her recently, on visiting her at the Venetian hospice, rotten and paralyzed by disease and old age. The exhilarating event at the concert hall ends, significantly, not with ritual applause and acclamation but with a perplexed silence, ${ }^{15}$ while Fred, turning to the audience envisions Mick's image. A cathartic finale...

Before discussing the critical comments mentioned above, I must confess that I have my own slight reservations about the film: some scenes appear to be superfluous or too lengthy. Thus, Mick's hallucination (obviously inspired by Fellini), in which the leading ladies of his films gradually appear on a meadow, has somehow an artificial flavor and could easily be disposed of. At times, "he who adds, detracts." For all its possible metaphorical value, the interlude in which Pseudo-Maradona, made to look like a huge balloon, repeatedly kicks a tennis ball into the air is far too lengthy to my taste, if necessary at all. Another criticism refers to the psychological verisimilitude of Mick's claim that he hardly remembers anything of his childhood, which is highly problematic on the cognitive level: the elderly remember this stage in their life-cycle much more clearly than recent events. But these minor reservations cannot diminish the remarkable value of this film as a work of art on aging.

For all its simplicity, the plot was misinterpreted by some critics, as "going nowhere," "lacking a trajectory," and a proper rhythm. However, it is well structured, based on a balanced mixture of tragic and comic elements and on a binary approach - two main protagonists with two life passions, actually two concentric plots. The binary approach is complementary to the dichotomy of themes, characters, images and sounds. Far from being "an emotionally paralyzed film about emotionally paralyzed people" it is profoundly sensitive and humane. I am leaving aside critical comments made from a moralist perspective, such as arrogance and sexism, which have no grounds at all. As to the "fragmentary nature of the film," Sorrentino may suggest an answer by referring to the German early-Romantic philosopher Novalis. ${ }^{16}$ Owing to his ideas on memory, past, artistic creativity and fragmentation, Novalis could have been a source of inspiration for Sorrentino. Noteworthy in this respect is the central role of the fragment and of the attempt to achieve a powerful totality by means of fragmentation in Novalis' philosophy of aesthetics. ${ }^{17}$ By the way, Novalis' fondness for aphorisms may be associated with another typical trait of the film. On the whole, even if at first glance various scenes may look as autonomous fragments, one can hardly deny that they do coalesce into an artistic entity through a coherent method of association between characters, themes and images. The film's slow rhythm befits some of its main motives and basic traits, such as the lethargy of mind stemming from aging, apathetic attitudes, the contemplative temperament of the main protagonists, the predilection for 
a comedy of manners on the one hand and for continual meditation on the other, a mood of languid indolence and the prevailing atmosphere of melancholy. But similar to the rhythm of its music, the film's rhythm is not monotonous: some of its sequences are more static, others more dynamic.

One of its most prominent characteristics (neglected by reviewers) is the predominance of nonverbal communication over the verbal. The latter tends to be laconic. Nonverbal communication, extremely abundant, is present on many channels: long silences, crying and laughter, smiles and frowns, grimaces and other facial expressions, various gestures, nudity and multi-cultural codes of dress, slaps on the cheek or caresses, massage touches. At times, there is a sharp contrast between the verbal and the nonverbal: e.g., Fred's words of gratitude to his wife are answered by a terrifying morbid silence. There is also an elderly wealthy couple, left anonymous, who never talk, yet exhibit a wide array of nonverbal expressions, including a totally unexpected slap of the lady on her partner's face. This couple is a subject of interest for Fred and Mick: amusingly, they bet on their verbal habit, and in a refreshingly voyeuristic scene, they contemplate, frustrated, the "mute" pair's copulation in the forest. The acerbic verbal confrontation between Mick and Brenda ends with her delicate, sympathetic caress on his cheek, a nonverbal means which, though meant perhaps to alleviate the pain caused by the verbal slap, can only intensify that emotion by revealing through that human sympathy the sincerity of her verbal invective (Significantly, Mick's last sentence attributes total value to emotions). Fred confesses being handicapped in the realm of the words (though actually he is not): "Music is all I understand...because you don't need words." The predominance of nonverbal communication in the film particularly suits the mental world of a man who has dedicated all his life to music. Worthy of mention in this respect is the memorable scene in which Fred, like a magician, alone in the heart of nature, conducts a choir of cows, all moving with their bells in full conformity with his directions - an outstanding fusion of landscape and soundscape.

As noted, Sorrentino was blamed for abusing nudity. But nudity, as an important channel of nonverbal communication, is manipulated in the film with finesse and artistic dexterity. In certain respects nudity is parallel to silence: both channels can reduce to their limit (or to nihil) two of the most basic characteristics of the human being as a "political animal" (in Aristotelian terms) - speech and dress. The complex nature of nudity is shown by its ability to arouse diametrically opposed feelings: shock or delight, lust or sexual repulsion, satisfaction or frustration. Nudity may belong to the realm of the sublime and the divine or to that of the vulgar or the grotesque. Asked by Fred who is the naked lady stepping into the water (Miss Universe, of course), Mick replies simply "God!." (note: not just a goddess...) Indeed, nudity can reveal nonflattering transformations undergone by the aging body, as opposed to the aesthetic aspect of a youthful one. This contrast and its related aspects are essential to the dialectic method of the film and to its subject matter. But there is no trace of youth-cult here. Bradshaw's association of the film's title in Italian (Giovinezza) with the fascist propaganda cult of youth has no real anchor in the film. ${ }^{18}$ Sorentino's multifarious use of nudity in Youth may be compared with some of his other films, especially The Great Beauty (2013) and the recent Loro (2018), focused on Berlusconi's old age (in this case, aging and politics).

As to verbal communication, the script is pregnant with witty aphorisms (not "clichés" or "empty epigrams," as some critics claimed), the understanding of which at times demands further reflection. ${ }^{19}$ Moreover, there is much ambiguity in the script. Witness, for instance, the solemn proclamation of the spa doctor foretelling Fred, like an enigmatic oracle, that youth is 
waiting for him outside. One critic, who oddly complained in this respect about lack of clarity in the film's sayings, raised the question: "Does he mean to say by this that youth and old age are only states of consciousness?" 20 This is, of course, possible, but there are additional possibilities: when such a statement is addressed to an octogenarian, even a healthy one, it is hard to miss the inversion irony implied by the film's title as well. Yet the doctor's "oracular" prophecy may also serve, in classical terms, as a dramatic anticipation of the final event, the concert in which a galvanized, rejuvenated Fred is conducting his youthful composition, Simple Songs, with the full energy of his youth. The script contains many sensitive observations, often imbued with bitter irony or delicate humor, on youth, senescence, love, frustration, memory, oblivion, parenthood and artistic creativity. Sorrentino has the magic ability to associate these observations with appropriate images and sounds, and thereby transform them into a state of mind, to use T.S. Eliot's words (referring to another context - poetry) ${ }^{21}$ This state of mind tends to be most of the film melancholic, nostalgic, full of sad reflections on the fragility of the human being, the brevity of life and the troubles of old age. Ars longa, vita brevis ("Art is long, life is short"), says a Latin aphorism. In a memorable scene, Mick ("a magician of metaphor," as Fred depicts him) is using a telescope in front of the Alpine panorama in order to reveal to his young assistants, metaphorically, the difference in perspective between the past and the future by spinning the instrument around 180 degrees.

Another complaint, which in my opinion appears to have missed Sorrentino's point, is that of having marooned most of the film in a spa. But that spa is a multi-dimensional symbol: in a sense, it becomes the center of the universe, a remarkably cosmopolitan place, a microcosm containing that impressive human gallery, to which Miss Universe herself is appropriately attached. The spa is also a sort of a luxurious prison (the metaphor is mentioned explicitly with respect to the name of a painting "Alpine prison") -- an artificial, sterile, suffocating and decadent place, in sharp contrast with its vibrant surrounding landscape. A carefully choreographed scene typical in this respect is that of the spa residents, all in white bath robes (a sort of uniform), floating gracefully at the sounds of harmonious music, as if they were levitating puppets or marionettes. But the spa also plays the role of a self-imposed exile from the real world, a refuge of escapism (for Fred) and a place to contemplate and make an ultimate attempt at artistic creativity (for Mick). As far as Mick's tragedy is concerned, the confinement to this location may also be associated with the unity of space, a dimension that complements the other classical elements: the chorus, the dea ex machina, the central confrontation, the tragic reversal, the subsequent tragic recognition (anagnorisis in Aristotelian terms) and inevitable death of the protagonist, the final catharsis. It is significant in this respect that Mick, the tragic hero (or antihero), unlike Fred, never leaves that place. The film's focus on wealthy people, also censured by some critics, is organically connected with the choice of that location, but the rich are far from being depicted as happy or incarnating an ideal. For all their wealth, they cannot escape life's frustrations and the vicissitudes of aging. This certainly holds true also as far as the two protagonists are concerned: they must be relatively wealthy to afford to stay there, but Sorrentino is interested in their art and aging problems and dilemmas, not in their wealth.

A critical comment which deserves special attention is that the film touches upon a series of serious topics lightly, without a dimension of depth. But Sorrentino is a priori aware of this problem: early in the film, Fred notes that levity is an irresistible temptation, but also a perversion. (But too much gravitas appears to be a perversion as well, at times perhaps even a worse one). The importance of levity is stressed through the recurring image of a taciturn 
Buddhist monk and the associated verb "to levitate" used in the context. But it is significant that in order to levitate that monk has to meditate. The apparently minor, light minded, way in which Sorrentino treats highly serious subjects of human life is not a slip; it is his fully conscious (and legitimate) choice, which conveys by itself a message. One should, however, remember in this respect that "Simple Songs" may ultimately reveal a surprisingly levitating complexity. There is no point in comparing Youth's complexity to that of The Great Beauty; despite certain similarities (e.g., antithetic images and sounds, preoccupation with aging and artistic creativity, the impact of a frustrated youth love, the melancholic atmosphere) the films are so different, and each should be judged by its own merits. The assertion that "Youth is not a simple song, just a simplistic one" is in my opinion severely misguided. ${ }^{22}$ Far from being simplistic, it is a profoundly humane and subtle cinematic rhapsody on old age.

\section{Conclusion and Epilogue}

Finally, I shall try to elucidate the subtlety and sophistication of this film through what prima facie appears to be a marginal example -- a person who never appears on the screen: Gilda Black, the youth passionate love of both protagonists, who appears in a sort of life-review typical of old age. The frustration over not having consummated that love, coupled by the suspicion that his friend had succeeded in doing that, continued to obsess Fred' life-reviews ${ }^{23}$ in spite of the sixty years which have elapsed. Towards the end of the film it becomes quite clear that Mick had also kept Gilda Black deep in his soul, although he had never been able to admit and confess that to his friend. The scene of his promenade in darkness and silence, hand in hand, with a melancholic hooker on the eve of his suicide, a scene meant by Mick, as both tragic hero and film director, to reproduce his memorable childhood walk with Gilda Black (of which typically we hear only after his death) is conceived in the best spirit of the Italian cinematic tradition.

But, one may ask, what's in a name? Well, in this case the name itself, Gilda Black, is an ingenious invention, impressively rich in connotations: On the cinematic level, Mick's artistic field - the black-and-white film noir Gilda (1946), starring Rita Hayworth in her iconic black dress of femme fatale. ${ }^{24}$ On the musical level, Fred's artistic field - Gilda, Rigoletto's daughter, enamored for the first time in life, in Verdi's opera; incidentally, Gilda's original name in Victor Hugo's play (Le roi s'amuse) on which the opera is based was Blanche, which raises the oxymoronic association black and white (Black Blanche) - the dress code of musical conductors. ${ }^{25}$ On the cognitive level, when pressed by Fred to confess whether he had ever made love to that woman, Mick answers sadly: "The real tragedy is that I can't even remember if I slept with Gilda Black" (in psychological terms this appears to be a sort of feigned blackout, aimed at leaving his friend, Fred, in doubt). But, finally and most obviously, Gilda Black is associated with Melany, Fred's wife, whose name is derived etymologically from the color "black" in Greek, and thereby with the film's binary method and melancholic atmosphere. Sorrentino's onomastic invention perfectly fits this threnody for senectitude. 
International Conference on NEW TRENDS IN SOCIAL SCIENCES

\section{References}

${ }^{1}$ See, e.g., Anthony Lane, "Toil and Trouble," New Yorker, July 12, 2015: "The plot goes round and round and nowhere"; Paul Byrnes, "Age in the Eye of the Beholder," Sydney Morning Herald, December 21, 2015: "As drama, it lacks a trajectory"; Mark Kermode, "Youth review Dazed and Confused," Observer, January 1, 2016; Bilge Ebiri, "Youth ," Vulture, February 4, 2015: "an emotionally paralyzed film about emotionally paralyzed people"; Geoffrey Macnab, "Youth, Film Review," Independent, January 28, 2016: "too flighty to allow its actors to bring much depth or pathos to their character."

${ }^{2}$ See, e.g., Ebiri, "Youth,": "...the fragmentary nature of the whole film, its seeming lack of rhythm and purpose"; Michael O'Sullivan, " 'Youth' Cloys, despite Gorgeous Visuals," Washington Post, December 9, 2015: "A collection of vignettes straining to coalesce into a satisfactory resolution."

3 See, e.g., Stephen Whitty, "Youth," Daily News, December 2, 2015: " The Yellow Pages listings would be an improvement over the script"; Alan Rapp, " 'Youth,' RazorFine, December 25, 2015: "clichéd sentimental tropes"; Giovanni Marchini Camia, "Youth Cannes 2015 Review," The Film Stage, May 20, 2015: "the hollow pomposity of the script"; "Youth is not a simple song, just a simplistic one"; David Calhoun, "Youth Review," Time Out, May 20, 2015: "fondness for empty epigrams."

4 See, e.g., Peter Bradshaw, "Life and Death as Seen from a Luxury Hot Tub," Guardian, January 28, 2016: "the kind of stylishness that risks depleting substance"; Robbie Collin, "Youth Review: A Plunge Pool of a Film," Telegraph, January 28, 2016: "For depth dip elsewhere"; Tara Brady, "A Vague, Beautiful Looking Meditation on...What Exactly ?," The Irish Times, March 24, 2016: "artistic but empty, vivid but vapid."

${ }^{5}$ See, e.g., Bradshaw, "Life and Death": "bizarre, new realistic tableaux of ugly people in various states of undress"; Erica Abeel, "Film Review: Youth," Film Journal International, December 2, 2015: "the year's most phallocentric film"; A.O. Scott, "Sorrentino's ' Youth': A Euro Buddy Film," New York Times, December 3, 2015:"sexist" and "boring."

${ }^{6}$ See, e.g., Peter Bradshaw, "Youth Review," Guardian, May 20, 2015; J. Don Birnam, "Youth Review," ComingSoon.net, September 19, 2015: "pampered brats", ".. these exceedingly rich people...seem almost impossible to connect with."

${ }^{7}$ See, e.g., Bradshaw, "Life and Death" (above, note 4); Scott, "A Euro Buddy Film"; Collin, "A Plunge Pool of a Film"; Phil De Semlyen, "Youth Review," Empire, January, 26, 2016. Old age has a central place also in Sorentino's recent film Loro (1918), dealing with Berlusconi.

8 E.g.: "A candidate for the season's most irritating and pretentious film." - Abeel, "Youth" (above, note 5); cf. Joe Morgenstern, " 'Youth' Review: the Old and the Restless," Wall Street Journal, December 3, 2015: "From early on my strong desire was for this horrible phantasmagoria to be over"; Michael O'Sullivan, " 'Youth' Cloys," December 9, 2015: "I'm not sure the buzz of watching it is worth the headache of the morning after."

9 See e.g. Kate Muir, "Youth," The Times, January 29, 2016; Dominick Suzanne-Meyer, "Film Review: 'Youth,' "Consequence of Sound, December 10, 2015, Alexandre Jourdain, "Youth - La 
Critique du Film: Boulevard du Crepuscule," aVoir-aLire.com, September 4, 2015, who nevertheless ascribes Sorrentino a lack of modesty. For the most favorable reviews, see Jay Weissberg, "Cannes Films Review:' Youth,' " Variety, May 20, 2015 and David Salazar, "Youth Movie Review," Latin Post, December 4, 2015.

10 The name appears to be associated with a prestigious champagne: Bollinger, vieilles vignes françaises blanc de noirs (old French vines white from black, i.e. white wine from dark grapes) an onomastic subtlety strangely missed by critics.

11 Cf. Weissberg, "Cannes Films Review" (above, note 9).

12 See Aristotle, Poetics, 1452a.

${ }^{13}$ Even this tragic confrontation has a comic touch associated with aging: at first Mick suspects that Brenda is afraid of being depicted as an old woman in his film and tries to brush that image away as a "poetic license," only to learn a moment later about her role in that TV serial - an alcoholic granny.

${ }^{14}$ Emile Durkheim, Le Suicide ${ }^{3}$ (Paris: F. Alcam, 1930), 264-331.

${ }^{15}$ For the significance of silence in the film, see below.

16 This is a literary pseudonym of Georg Philipp Friedrich von Hardenberg (1772-1801).

17 See, e.g., Laurie Ruth Johnson, The Act of Recollection in Jena Romanticism (Tübingen: Max Niemayer, 2002), 1-141.

18 "Life and Death" (above, note 4).

${ }^{19}$ E.g., the strangely provocative dictum ascribed to Igor Stravinsky that intellectuals have no taste appears to be best understood on the ground of their predilection for the verbal, their high evaluation of words.

${ }^{20}$ Uri Klein, "Drowning in a Spa," Haaretz, March 11, 2016.

21 "The Metaphysical Poets," in D.J. Enright and Ernst de Chickera (eds.), English Critical Texts (Oxford: Oxford University Press, 1962), 302-311, especially at p. 310.

22 See above, note 3 .

23 For life-reviews and old age see, e.g., R.N. Butler, "The Life-Review," in P.L. McKee (ed.), Philosophical Foundations of Gerontology (New York: Human Sciences Press, 1982), 219-242.

24 There is an obvious hint to this film in the script.

${ }^{25}$ Fred's surname, Ballinger, may also be associated with black and white through the Bollinger champagne: see above, note 10 . 